\title{
KONTRIBUSI USAHA BUDIDAYA LEBAH MADU (TRIGONA SP) TERHADAP PENDAPATAN RUMAH TANGGA PETANI DI KECAMATAN BAYAN KABUPATEN LOMBOK UTARA
}

\section{THE CONTRIBUTION OF (TRIGONA SP) HONEY BEESTOWARDS INCOME OF FARMER HOUSEHOLDS IN BAYAN SUB-DISTRICT OF NORTH LOMBOK DISTRICT}

\author{
Susi Ardiani Rahmayanti ${ }^{1 *}$, M. Yusuf ${ }^{2}$, Syarif Husni ${ }^{3}$ \\ ${ }^{1}$ Mahasiswa Program Studi, Argribisnis, Fakultas Pertanian, Universitas Mataram \\ ${ }^{2,3}$ Dosen program Studi Agribisnis, Fakultas Pertanian, Universitas Mataram \\ *E-mail: Susiardd@gmail.com
}

\begin{abstract}
ABSTRAK
Penelitian ini bertujuan untuk: (1) Menganalisis biaya dan pendapatan usaha budidaya lebah madu Trigona sp di Kecamatan Bayan Kabupaten Lombok Utara; (2) Menganalisis Kontribusi usaha budidaya lebah madu Trigona sp terhadap pendapatan rumah tangga petani di Kecamatan Bayan Kabupaten Lombok Utara; (3) Mengetahui kendala-kendala yang dihadapi pelaku usaha budidaya lebah madu Trigona sp di Kecamatan Bayan Kabupaten Lombok Utara. Metode yang digunakan dalam penelitian ini adalah metode deskriptif, sedangkan pengumpulan data dilakukan dengan menggunakan teknik survei.

Hasil penelitian menunjukkan bahwa: (1) Rata-rata biaya produksi usaha budidaya lebah madu Trigona $s p$ di Kecamatan Bayan Kabupaten Lombok Utara sebesar Rp 5.270/stup atau Rp 247.668/proses produksi atau $\mathrm{Rp}$ 495.336/tahun dengan nilai penerimaan sebesar Rp 36.503/stup atau Rp 1.715.625/proses produksi atau Rp 3.431.250/tahun. Sementara itu rata-rata pendapatan yang diperoleh petani lebah madu sebesar Rp 31.233/stup Rp 1.467.957/proses produksi atau Rp 2.935.914/tahun; (2) Kontribusi usaha budidaya lebah madu Trigona sp terhadap pendapatan rumah tangga petani di Kecamatan Bayan Kabupaten Lombok Utara sebesar Rp 2.935.914 $(21,68 \%)$ dari total pendapatan Rp 13.695.676/tahun yang bersumber dari sektor pertanian Rp 6.254.762 (46,19\%) dan usaha non pertanian $\operatorname{Rp} 4.350 .000$ (32,13\%); (3) Kendala utama yang dihadapi petani dalam melakukan usaha budidaya lebah madu Trigona sp di Kecamatan Bayan Kabupaten Lombok Utara adalah koloni dan teknologi dikarenakan keterbatasan koloni dan teknologi yang dimiliki oleh petani, modal, iklim, pendidikan/keterampilan, hama dan pakan.
\end{abstract}

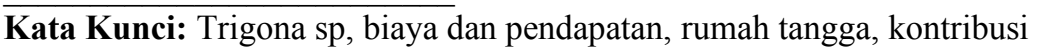

\section{ABSTRACT}

This research aims to: (1) Analyze cost and income of the Trigona sp honey bee business in Bayan SubDistrict of North Lombok District; (2) Analyze the contribution of Trigona sp Honey bee toward income of farmer household in Bayan Sub-District of North Lombok District; (3) Understand the problems faced by farmers in Trigona sp. Honey bee business in Bayan Sub-District of North Lombok District. The methods in use is descriptive, while the data collection is using survey techniques.

The result of the study show (1) The average production cost of Trigona sp honey bee business in Bayan Sub-District of North Lombok District is Rp. 5.270/stup or Rp. 247.668/production or Rp. 495.336/years. Then the aquired value of this business is Rp. 36.503/stup or Rp. 1.715.625/production or Rp. 3.431.250/years. While the average income which aquired by bee farmers is Rp. 31.233/stup, Rp. 1.715.625/production, or Rp. 2.935.914/years; (2) The contribution of Trigona sp. Honey bee towards income of farmer households in Bayan Sub-District of North Lombok District is Rp.2.935.914 (21,68\%), from total income Rp. 13.695.676/years which are from agricultute sector $R p .6 .254 .762$ (46,19\%) and from non-agriculture sector Rp. 4.350 .000 (32,13\%); (3) The main problems that faced by farmers when conducting Trigona sp honey bee in Bayan SubDistrict of North Lombok District is the colony of Trigona's bees and technology, investment, the climate, education and skill that experienced, pest and bees forage.

Key Words: Trigona sp, cost and income, household, contribution. 


\section{PENDAHULUAN}

Indonesia memiliki potensi sumber daya alam yang cukup besar dan berlimpah. Kekayaan yang terkandung di dalamnya sangat beraneka ragam terutama dari hasil hutan, baik berupa hasil hutan kayu (HHK) maupun hasil hutan bukan kayu (HHBK). Hasil hutan bukan kayu merupakan salah satu sumber daya alam yang memiliki nilai ekonomis, salah satunya yaitu madu. Madu berasal dari hewan yang masih hidup (lebah) (Ichwan, et al,.2016).

Lombok Utara (KLU) merupakan salah satu lokasi penghasil madu yang cukup potensial di Nusa Tenggara Barat (NTB). Sebagian besar madu yang dihasilkan di KLU berasal dari hasil budidaya maupun perburuan secara alami. Budidaya lebah madu memiliki prospek yang cukup baik untuk dikembangkan di KLU adalah jenis Trigona sp. Lebah madu jenis Trigona sp merupakan salah satu lebah madu yang mudah untuk di pelihara karena mudah beradaptasi dengan lingkungan sekitarnya. Salah satu wilayah di KLU yang banyak melakukan usaha budidaya terhadap lebah madu Trigona sp adalah Kecamatan Bayan.

Teknik Budidaya lebah madu Trigona sp di Kecamatan Bayan masih dilakukan secara sederhana dan tradisional mulai dari penggunaan media kembangbiak lebah hingga alat yang digunakan. Saat ini pelaku usaha lebah Trigona sp di Kecamatan Bayan terus meningkat setiap tahunnya, hal ini dapat dilihat dari jumlah kelompok dan anggota yang terdaftar dalam data kelompok-kelompok tani hutan (Penyuluh Kehutanan, 2016). Perkembangan usaha ini merupakan sebuah hal yang positif untuk meningkatkan pendapatan kesejahteraan dari pelaku usaha budidaya lebah madu Trigona sp (Zulfikri, et, al., 2014)

Budidaya lebah madu Trigona sp memberikan manfaat secara langsung maupun tidak langsung. Manfaat langsung yang diperoleh dan memiliki manfaat paling banyak yaitu madu dan propolis, sedangkan manfaat tidak langsung yaitu peningkatan produksi pertanian, perkebunan, dan kehutanan, peningkatan kesehatan masyarakat, membuka kesempatan kerja dan usaha, meningkatkan kesejahteraan dan pendapatan masyarakat (Marhiyanto, 1999) dalam (Wardoyo, et, al., 2016).

Pendapatan rumah tangga petani tidak hanya berasal dari kegiatan usaha budidaya lebah madu Trigona $s p$, namun juga bersumber dari pendapatan on farm, off farm maupun non farm. Pendapatan usahatani (on farm) merupakan pendapatan yang diperoleh dari kegiatan bercocok tanam, usahatani padi, jagung maupun usaha tanaman lainnya. Pendapatan luar usahatani (off farm) yaitu dari hasil kegiatan sebagai buruh tani, beternak dan salah satunya adalah melakukan usaha budidaya lebah madu. Sedangkan pendapatan diluar pertanian ( $n o n$ farm) yaitu pendapatan yang diperoleh dari kegiatan berdagang, pegawai negeri/swasta, dan lain-lain ( Filly, 2018).

Dalam berusaha budidaya lebah madu tidak terlepas dari biaya produksi atau biaya yang harus dikeluarkan oleh petani untuk dapat memproduksi madu. Biaya yang dikeluarkan seperti bibit, pakan, tenaga kerja, peralatan, stup atau glodok dan alat penunjang lainnya. Tujuan melakukan usaha budidaya lebah madu ini untuk meningkatkan pendapatan. Kegiatan usaha budidaya lebah madu memiliki peranan yang penting sebagai salah satu strategi dalam mencukupi perekonomian rumah tangga petani. Namun tidak semua petani sadar akan besarnya kontribusi usaha budidaya lebah madu yang dijalankan terhadap pendapatan rumah tangga mereka.

Berdasarkan uraian di atas maka yang menjadi permasalah dalam penelitian ini adalah: (1) Seberapa besar biaya dan pendapatan dari usaha budidaya lebah madu jenis Trigona sp di Kecamatan Bayan Kabupaten Lombok Utara?; (2) Seberapa besar kontribusi usaha budidaya lebah madu jenis Trigona sp terhadap pendapatan rumah tangga petani di Kecamatan Bayan Kabupaten Lombok Utara?; (3) Kendala-kendala apa saja yang dihadapi peternak lebah madu Trigona sp dalam melakukan usaha budidaya lebah madu jenis Trigona sp di Kecamatan Bayan Kabupaten Lombok Utara? Berdasarkan rumusan masalah di atas maka dilakukan penelitian berjudul "Kontribusi Usaha Budidaya Lebah Madu Trigona sp Terhadap Pendapatan Rumah Tangga Petani di Kecamatan Bayan Kabupaten Lombok Utara"

Penelitian ini bertujuan untuk: (1) Menganalisis biaya dan pendapatan usaha budidaya lebah madu jenis Trigona sp di Kecamatan Bayan Kabupaten Lombok Utara; (2) Menganalisis Kontribusi usaha terhadap pendapatan rumah tangga petani usaha budidaya lebah madu jenis Trigona sp di Kecamatan Bayan Kabupaten Lombok Utara; (3) Mengetahui kendala-kendala yang di hadapi oleh pelaku usaha budidaya lebah madu jenis Trigona sp di Kecamatan Bayan Kabupaten Lombok Utara.

\section{METODE PENELITIAN}

Metode yang digunakan di dalam penelitian ini adalah metode deskriptif, sedangkan pengumpulan data dilakukan dengan teknik survei (Nazir, 2011). Unit analisis dalam penelitian ini adalah rumah tangga petani usaha budidaya lebah madu Trigona sp yang berada di Kecamatan Bayan Kabupaten Lombok Utara. Penelitian ini dilakukan di 2 (dua) desa yaitu Desa Mumbulsari dan Desa Persiapan Baturakit dengan teknik purposive sampling dengan pertimbangan bahwa kedua desa tersebut terdapat jumlah petani madu yang cukup banyak, dan masih aktif. Penentuan jumlah responden secara quota sampling yaitu sebanyak 40 petani responden dengan rincian 19 petani responden di Desa Mumbulsari dan 21 petani responden di Desa Persiapan Baturakit. Jenis data yang digunakan adalah data kuantitatif dan kualitatif, sumber data dari data primer dan data sekunder, variabel dan cara pengukuran dalam penelitian ini adalah (a) biaya produksi dan pendapatan usaha budidaya 
lebah madu Trigona sp, (b) kontribusi usaha budidaya lebah madu Trigona sp; (c) Kendala usaha budidaya lebah madu Trigona sp.

Data dianalisis secara deskriptif. Adapun rumus yang digunakan meliputi rumus biaya dan pendapatan usahatani dengan analisis $\Pi=$ TR-TC; dimana $\Pi=$ Pendapatan usahatani $(\mathrm{Rp})$ dan $\mathrm{TC}=$ Tota biaya Produksi (Rp) (Suratiyah, 2009). K = [PUT /(PUT +PL)] x 100\%, dimana K = Kontribusi (\%), PUT = Pendapatan usahatani lebah madu Trigona sp, PL = Pendapatan lain (Rp).

\section{HASIL DAN PEMBAHASAN}

\section{Karakteristik Responden}

Karakteristik petani responden usaha budidaya lebah madu Trigona sp di Kecamatan Bayan Kabupaten Lombok Utara di sajikan pada Tabel 1 berikut:

Tabel 1. Karakteristik Petani Responden Usaha Budidaya Lebah Madu Trigona sp di Kecamatan Bayan tahun

\begin{tabular}{|c|c|c|c|}
\hline No & Uraian & Keterangan & Persentase $(\%)$ \\
\hline 1 & Jumlah Responden (Orang) & 40 & \\
\hline \multirow[t]{3}{*}{2} & Umur (Tahun) & & \\
\hline & Rata-rata Umur & 42 & \\
\hline & Kisaran Umur & $28-65$ & \\
\hline \multirow[t]{7}{*}{3} & Tingkat Pendidikan & & \\
\hline & a. TS & 22 & 55 \\
\hline & b. TTSD & 2 & 5 \\
\hline & c. TSD & 6 & 15 \\
\hline & d. TSMP & 1 & 2,5 \\
\hline & e. TSSMA & 6 & 15 \\
\hline & f. S1 & 3 & 7,5 \\
\hline \multirow[t]{3}{*}{4} & Pengalaman Usaha (Tahun) & & \\
\hline & Rata-rata & 7 & \\
\hline & Kisaran & $2-17$ & \\
\hline \multirow[t]{3}{*}{5} & Jumlah Stup (Unit) & & \\
\hline & Rata-rata & 47 & \\
\hline & Kisaran & $2-200$ & \\
\hline \multirow[t]{3}{*}{6} & Jumlah Tanggungan (Orang) & & \\
\hline & Rata-rata & 5 & \\
\hline & Kisaran & $2-8$ & \\
\hline \multirow[t]{3}{*}{7} & Jenis Kelamin & & \\
\hline & a. Laki-laki & 39 & 97,5 \\
\hline & b. Perempuan & 1 & 2,5 \\
\hline
\end{tabular}

Sumber: Data Primer diolah 2019

Analisis Biaya Produksi dan Pendapatan Usaha Budidaya Lebah Madu Trigona sp di Kecamatan Bayan Kabupaten Lombok Utara

Rata-rata biaya produksi dan pendapatan yang diperoleh dari usaha budida lebah madu Trigona $s p$ di Kecamatan Bayan Kabupaten Lombok Utara di sajikan pada Tabel 2 berikut: 
Tabel 2. Rata-rata Biaya Produksi dan Pendapatan Usaha Budidaya Lebah Madu Trigona sp di Kecamatan Bayan Kabupaten Lombok Utara dalam Satu Tahun 2018

\begin{tabular}{|c|c|c|c|c|c|}
\hline No & Jenis Biaya & Jumlah Fisik & $\begin{array}{c}\text { Nilai } \\
\text { (Rp/Stup) }\end{array}$ & $\begin{array}{l}\text { Nilai (Rp/Proses } \\
\text { Produksi ) }\end{array}$ & Nilai (Rp/Tahun) \\
\hline \multirow[t]{8}{*}{1} & $\begin{array}{l}\text { Biaya Variabel } \\
\text { a. Biaya Saprodi (Rp) }\end{array}$ & & $(2.537)$ & $(119.218)$ & $(238.435)$ \\
\hline & - Koloni & 47 & 2.509 & 117.938 & 235.876 \\
\hline & - Botol & 26 & 27 & 1.280 & 2.560 \\
\hline & c. Biaya Tenaga Kerja & 2,02 & $(1.075)$ & $(50.514)$ & $(101.027)$ \\
\hline & - Pemeliharaan (HKO) & 0,27 & 144 & 6.764 & 13.527 \\
\hline & • Panen (HKO) & 1,29 & 682 & 32.054 & 64.107 \\
\hline & - Pengemasan (HKO) & 0,46 & 249 & 11.697 & 23.393 \\
\hline & \multicolumn{2}{|l|}{ Total Biaya Variabel (Rp) } & $(3.611)$ & $(169.732)$ & $(339.462)$ \\
\hline \multirow[t]{11}{*}{2} & Biaya Tetap (Rp) & & & & \\
\hline & a. Penyusutan Alat & & $(1.658)$ & (77.937) & (155.874) \\
\hline & - Stup (unit) & 47 & 1.104 & 51.893 & 103.785 \\
\hline & - Gergaji (buah) & 1 & 94 & 4.425 & 8.850 \\
\hline & • Palu (buah) & 1 & 26 & 1.212 & 2.423 \\
\hline & - Pisau (buah) & 1 & 30 & 1.396 & 2.791 \\
\hline & • Baskom (Buah) & 1 & 25 & 1.166 & 2.331 \\
\hline & - Saringan (Buah) & 1 & 13 & 612 & 1.224 \\
\hline & • Sendok (buah) & 1 & 4 & 200 & 400 \\
\hline & - Rak (unit) & 1 & 360 & 16.900 & 33.800 \\
\hline & - Tali (m) & 3 & 3 & 135 & 270 \\
\hline \multicolumn{2}{|r|}{ Total Biaya Produksi (Rp) } & & $(5.270)$ & 247.668 & 495.336 \\
\hline 3 & Produksi Madu (Liter) & & 0,16 & 7,625 & 15,25 \\
\hline 4 & Harga Madu (Rp/Liter) & 225.000 & 4.787 & 225.000 & 225.000 \\
\hline 5 & Penerimaan (Rp) & & 36.503 & 1.715 .625 & 3.431 .250 \\
\hline 6 & Pendapatan (Rp) & & 31.233 & 1.467 .957 & 2.935 .914 \\
\hline 7 & R/C Ratio & & 6,93 & 6,93 & 6,93 \\
\hline
\end{tabular}

Sumber: Data Primer diolah, 2019

Berdasarkan Tabel 2 dapat diuraikan hal-hal sebagai berikut: Rata-rata biaya sarana produksi untuk usaha budidaya lebah madu Trigona sp sebesar Rp 5.270/stup atau Rp 247.668/proses produksi atau Rp 495.336/tahun, proses produksi terjadi selama dua kali dalam satu tahun. Biaya produksi terdiri dari biaya variabel sebesar Rp 3.611/stup atau Rp 169.731/proses produksi atau Rp 339.467/tahun, meliputi biaya saprodi yang terdiri atas koloni sebesar Rp 2.509/stup atau Rp 117.93/proses produksi atau Rp. 235.875/tahun dan botol sebesar Rp 27/stup atau Rp 1.280/ proses produksi atau Rp 2.560/tahun, harga botol sangat murah dikarenakan botol yang digunakan oleh petani yaitu botol bekas seperti botol air minum kemasan $600 \mathrm{ml}$ dan botol kecap $600 \mathrm{ml}$ yang kemudian dibersihkan. Biaya variabel lainnya yaitu biaya tenaga kerja, yang meliputi biaya pemeliharaan, pemanenan dan pengemasan. Tenaga kerja yang digunakan yaitu hanya tenaga kerja dalam keluarga karena usaha ini tidak membutuhkan tenaga yang cukup banyak dalam pengerjaannya. Rata-rata biaya tenaga kerja yang dikeluarkan oleh petani sebesar Rp 1.075/stup atau Rp. 50.514/proses produksi atau Rp 101.027/ tahun, dengan total penyerapan rata-rata tenaga kerja 2 (dua) orang atau 2,02 HKO/tahun. Sementara untuk biaya tetap bersumber dari biaya penyusutan alat sebesar Rp 5.270/stup atau Rp 77.937/proses produksi atau Rp 155.874/tahun. Penyusutan bersumber dari stup, gergaji, palu pisau, baskom, saringan, sendok, rak dan tali, dengan rata-rata jumlah untuk masing-masing alat sebanyak 1 (satu) kecuali untuk tali dengan rata-rata sebanyak 3 (tiga) meter.

Rata-rata produksi yang dihasilkan dari usaha budidaya lebah madu Trigona sp sebanyak sebanyak 0,16 liter/stup atau 7,625 liter/proses produksi atau 15,25 liter/tahun, jumlah produksi bersumber dari 47 stup. Jika dikaitkan dengan harga satu liter madu Rp 225.000 maka diperoleh nilai produksi sebesar Rp 36.503/stup atau Rp 1.715.625/proses produksi atau Rp 3.431.250/tahun. Apabila nilai produksi dikurangi dengan biaya produksi Rp 5.270/stup atau Rp 247.668/proses produksi atau Rp 495.336/tahun maka diperoleh pendapatan sebesar Rp 31.233/stup atau Rp 1.467.957/proses produksi atau Rp 2.935.914/tahun. Nilai R/C ratio sebesar 6,93. Artinya setiap penggunaan input sebesar Rp 1,- (satu satuan rupiah) akan menghasilkan penerimaan sebesar Rp 6,93 sehingga usaha tersebut layak dikembangkan jika dilihat dari biaya yang dikeluarkan dan penerimaan yang diperoleh. 
Analisis Biaya Produksi dan Pendapatan pada Sektor Pertanian di Kecamatan Bayan Kabupaten Lombok Utara

Pendapatan rumah tangga lainnya bersumber dari sektor pertanian, yang berasal dari usahatani jagung dan usahatani perkebunan (jambu mete+kelapa). Rata-rata pendapatan petani lebah madu dari sektor pertanian disajikan pada Tabel 3 berikut:

Tabel 3. Rata-rata Produksi dan Pendapatan Petani dari Sektor Pertanian dalam Satu Tahun di Kecamatan Bayan Kabupaten Lombok Utara Tahun 2018

\begin{tabular}{|c|c|c|c|}
\hline \multirow{2}{*}{ No } & \multirow{2}{*}{ Uraian } & \multicolumn{2}{|c|}{ Usahatani } \\
\hline & & Jagung & Mete+Kelapa \\
\hline 1 & Luas Lahan Garapan (Ha) & 0,12 & 0,84 \\
\hline \multirow[t]{4}{*}{2} & Biaya Variabel (Rp) & & \\
\hline & a. Sarana Produksi & 235.442 & 274.688 \\
\hline & b. Biaya Tenaga Kerja & 285.000 & 1.202 .500 \\
\hline & Total Biaya Variabel (Rp) & 520.442 & 1.477 .188 \\
\hline \multirow[t]{4}{*}{3} & Biaya Tetap (Rp) & & \\
\hline & a. Penyusutan Alat & 24.825 & 50.408 \\
\hline & b. Pajak Lahan & 5.875 & 42.000 \\
\hline & Total Biaya Tetap (Rp) & 30.700 & 92.408 \\
\hline \multirow{4}{*}{4} & Total Biaya Produksi (Rp) & 551.142 & 1.569 .596 \\
\hline & \begin{tabular}{|l} 
Produksi \\
a. Jagung $(\mathrm{kg})$
\end{tabular} & 295,00 & \\
\hline & b. Mete (Gelondongan $/ \mathrm{kg}$ ) & & 265 \\
\hline & c. Kelapa (Butir) & & 1.154 \\
\hline \multirow[t]{4}{*}{5} & Harga & & \\
\hline & a. Jagung $(\mathrm{Rp} / \mathrm{Kg})$ & 3.500 & \\
\hline & b. Mete $(\mathrm{Rp} / \mathrm{Kg})$ & & 19.000 \\
\hline & c. Kelapa (Rp/Butir) & & 2.000 \\
\hline \multirow[t]{4}{*}{6} & Nilai Produksi (Rp) & & \\
\hline & a. Jagung & 1.032 .500 & \\
\hline & b. Mete & & 5.035 .000 \\
\hline & c. Kelapa & & 2.308 .000 \\
\hline 7 & Nilai Produksi (Rp) & 1.032 .500 & 7.343 .000 \\
\hline 8 & Pendapatan (Rp) & 481.358 & 5.773 .404 \\
\hline 9 & Total Pendapatan Usahatani jagung+ (mete+kelapa) (Rp & \multicolumn{2}{|c|}{6.254 .762} \\
\hline 10 & $\mathrm{R} / \mathrm{C}$ ratio & 1,9 & 4,7 \\
\hline
\end{tabular}

Sumber: Data Primer diolah, 2019

Berdasarkan Tabel 3. dapat diuraikan hal-hal sebagai berikut: Rata-rata biaya produksi yang di keluarkan sektor pertanian untuk usahatani jagung sebesar Rp 551.142/tahun yang meliputi biaya variabel sebesar Rp 520.442/tahun dan biaya tetap sebesar 30.700/tahun. Sementara biaya untuk usahatani perkebunan (jambu mete+kelapa) sebesar Rp 1.569.596/tahun yang terdiri dari biaya variabel Rp 1.032.500/tahun dan biaya tetap Rp. 92.408/tahun.

Biaya variabel usahatani jagung bersumber dari biaya sarana produksi rata-rata sebesar Rp 235.442/ tahun yang terdiri dari biaya benih $\mathrm{Rp} 149.500$, pupuk $\mathrm{Rp} 51.875$, obat-obatan $\mathrm{Rp} 17.750$ dan karung $\mathrm{Rp}$ 16.297, sedangkan untuk biaya tenaga kerja sebesar Rp 285.000/ tahun dengan total HKO 5,44 yang terdiri dari

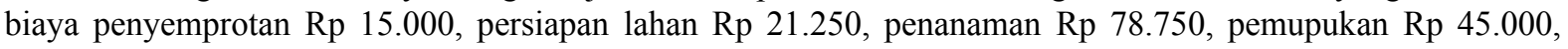
pemanenan Rp 67.500 dan pengangkutan Rp 57.500. Sementara itu biaya tetap berasal dari biaya penyusutan alat sebesar Rp 24.825.-/tahun yang terdiri dari Sprayer Rp 16.250, Sabit Rp 5.700 dan cangkul Rp 2.875, juga biaya pajak lahan sebesar Rp 5.875 .

Biaya variabel usahatani perekebunan (jambu mete+kelapa) bersumber dari biaya sarana produksi ratarata sebesar Rp 274.688.-/tahun yang terdiri dari biaya pupuk Rp 191.188. dan obat-obatan Rp 83.000, sedangkan untuk biaya tenaga kerja sebesar Rp 1.202.500., dengan total HKO 21,35 yang terdiri dari biaya penyemprotan $\mathrm{Rp}$ 120.000, pemupukan Rp 118.750. pemanenan Rp 827.500. dan pembersihan lahan $\mathrm{Rp}$ 136.250. Sementara itu biaya tetap berasal dari biaya penyusutan alat sebesar Rp 50.408. yang terdiri dari sprayer Rp Rp. 30.917, cangkul Rp 11.775 dan ember Rp 7.716, serta biaya pajak lahan sebesar Rp 42.000/ tahun.

Rata-rata produksi jagung yang dihasilkan petani sebanyak $290 \mathrm{~kg} /$ tahun dengan menggunakan harga

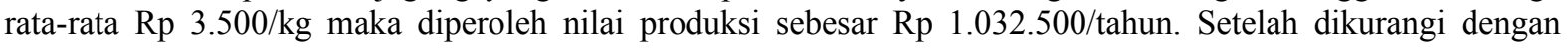
biaya produksi sebesar Rp 551.442/tahun maka diperoleh pendapatan sebesar Rp 481.358/tahun Sementara itu rata-rata produksi dari usahatani jambu mete dan kelapa sebanyak $265 \mathrm{~kg} /$ tahun dan $1.154 \mathrm{butir} / \mathrm{tahun}$ dengan 
harga rata-rata jambu mete $\mathrm{Rp}$ 19.000/kg (gelondongan) dan kelapa Rp 2.000/butir, maka diperoleh nilai produksi masing-masing untuk jambu mete $\mathrm{Rp}$ 5.035.000/tahun dan kelapa Rp 2.308.000/tahun, sehingga total penerimaannya sebesar Rp 7.343.000/proses produksi, setelah dikurangi dengan biaya produksi Rp 1.569.596/tahun maka diperoleh pendapatan untuk usahatani (jambu mete+kelapa) Rp 5.773.404/tahun. Apabila pendapatan usahatani jagung dengan usahatani (jambu mete+kelapa) dijumlahkan maka diperoleh total pendapatan dari sektor pertanian sebesar Rp 6.254.762/tahun.

Nilai R/C ratio untuk usahatani jagung sebesar 1,9 artinya setiap penggunaan input Rp 1.- (satu satuan rupiah) sebesar satu satuan rupiah akan menghasilkan penerimaan sebesar Rp 1,6 sehingga usaha tersebut layak diusahakan karena nilai $\mathrm{R} / \mathrm{C}$ ratio $>1$ (lebih besar dari satu) dimana usaha ini mampu memberikan keuntungan 1,6 kali dari biaya yang dikeluarkan. Sementara nilai $\mathrm{R} / \mathrm{C}$ ratio untuk usahatani perkebunan (jambu mete+kelapa) sebesar 4,7 nilai $\mathrm{R} / \mathrm{C}$ ratio artinya setiap penggunaan input sebesar $\mathrm{Rp} 1$,- (satu satuan rupiah) mengakibatkan penerimaan Rp 4,7,- sehingga usaha tersebut dikatakan layak karena nilai $\mathrm{R} / \mathrm{C}$ ratio $>1$ dan mampu memberikan keuntungan 4,7 kali dari biaya yang dikeluarkan.

\section{Pendapatan dari Sektor Non Pertanian}

Pendapatan sektor non pertanian berasal dari beberapa sumber. Rincian sumber pendapatan dari sektor non pertanian disajikan pada Tabel 4 berikut:

Tabel 4. Rata-rata Pendapatan dari Sektor Non Pertanian dalam Satu Tahun di Kecamatan Bayan Tahun 2018

\begin{tabular}{llr} 
No & Sumber Pendapatan & Rata-rata Pendapatan (Rp/Th) \\
\hline 1 & PNS & 1.350 .000 \\
2 & Guru Honor & 600.000 \\
3 & Kadus & 1.440 .000 \\
4 & Ibu Kader & 60.000 \\
5 & Tukang Bangunan & 900.000 \\
\hline \multicolumn{2}{l}{ Total Pendapatan } & $\mathbf{4 . 3 5 0 . 0 0 0}$ \\
\hline
\end{tabular}

Sumber: Data Primer diolah, 2019

Tabel 4 menunjukkan bahwa pendapatan tertinggi dari sektor non pertanian bersumber dari kadus (kepala dusun) dengan rata-rata pendapatan Rp 1.440.000/tahun. Selain menjadi kadus guru honor menjadi pekerjaan dengan jumlah yang sama dengan kadus yaitu sebanyak 4 (empat) orang, namun rata-rata jumlah pendapatan lebih sedikit yaitu sebesar Rp 600.000/tahun disebabkan guru honor memperoleh gaji yang lebih rendah perbulannya. Pendapatan lainnya bersumber dari PNS dengan rata-rata sebesar Rp 1.350.000/tahun dengan jumlah responden sebanyak satu orang, selanjutnya ibu kader Rp 60.000/tahun dengan jumlah responden satu orang dan tukang bangunan dengan rata-rata Rp 900.000/tahun dengan jumlah responden satu orang.

Kontribusi Usaha Budidaya Lebah Madu Trigona sp Terhadap Pendapatan Rumah Tangga Petani di Kecamatan Bayan Kabupaten Lombok Utara

Pendapatan rumah tangga yang dimaksud adalah total pendapatan yang diperoleh dari seluruh anggota rumah tangga yang bersumber dari berbagai pendapatan yaitu usaha budidaya lebah madu Trigona sp, usaha on farm dan usaha non farm yang diperoleh dari ibu, bapak, anak maupun anggota lainnya yang tinggal dalam satu rumah dan makan dalam satu anggaran. Rata-rata kontribusi usaha budidaya lebah madu Trigona sp terhadap pendapatan rumah tangga di Kecamatan Bayan dapat disajikan pada Tabel 5.

Tabel 5. Rata-rata Kontribusi Usaha Budidaya Lebah Madu Trigona sp Terhadap Pendapatan Rumah Tangga Petani di Kecamatan Bayan Tahun 2018

\begin{tabular}{|c|c|c|c|}
\hline No & Sumber pendapatan & $\begin{array}{c}\text { Jumlah pendapatan }(\mathrm{Rp} / \\
\text { Thn) }\end{array}$ & kontribusi $(\%)$ \\
\hline 1 & Usaha budidaya lebah madu trigona sp & 2.935 .914 & 21,68 \\
\hline 2 & Usaha jagung+perkebunan & 6.254 .762 & 46,19 \\
\hline \multirow[t]{2}{*}{3} & Usaha non-pertanian & 4.350 .000 & 32,13 \\
\hline & Total Pendapatan Rumah tangga & 13.540 .676 & 100,00 \\
\hline
\end{tabular}

Sumber: Data Primer diolah, 2019

Berdasarkan Tabel 5 dapat diuraikan sebagai berikut, rumah tangga petani di Kecamatan Bayan sebesar Rp 2.935.914 (21,68\%) dari total pendapatan Rp. 13.695.676/tahun. Rata-rata total pendapatan petani tersebut bersumber dari usaha budidaya lebah madu itu sendiri, sektor pertanian yaitu usahatani jagung dan perkebunan 
(jambu mete+kelapa) sebesar Rp 6.524 .762 (46,19\%) dan sektor usaha non pertanian Rp 4.350.000 (32,13\%) dari beberapa sektor usaha tersebut yang memberikan kontribusi terbesar pertama adalah usahatani perkebunan, karena rata-rata petani responden menjadikan sektor ini sebagai sektor utama penghasilan mereka. Kedua diikuti oleh sektor usaha non pertanian karena sebagian responden bekerja sebagai PNS, Guru Honor, Kadus, Ibu Kader dan Tukang Bangunan. Ketiga usaha budidaya lebah madu Trigona sp dikarenakan usaha ini merupakan usaha sampingan dari petani responden. Keempat usahatani jagung dikarenakan sedikitnya jumlah petani yang memiliki lahan sawah.

\section{Kendala dalam Usaha Budidaya Lebah Madu Trigona sp}

Usaha budidaya lebah madu Trigona sp tidak selalu berjalan dengan baik disebabkan oleh beberapa kendala yang dihadapi sehingga dapat mempengaruhi proses produksi, pendapatan dan lainnya. Kendalakendala yang dirasakan oleh petani disajikan pada Tabel 6 berikut:

\begin{tabular}{llcc}
\multicolumn{4}{c}{ Tabel 6. } \\
\hline No & Kendala Usaha Budidaya Lebah Madu Trigona sp & di Kecamatan Bayan Tahun 2018 \\
\hline 1 & Koloni+Teknologi & Jumlah Orang & Persentase (\%) \\
2 & Modal & 40 & 100,00 \\
3 & Pendidikan/Keterampilan & 35 & 87,50 \\
4 & Iklim & 14 & 35,00 \\
5 & Hama & 25 & 62,50 \\
6 & Pakan & 7 & 17,50 \\
\hline
\end{tabular}

Sumber: Data Primer diolah, 2019

\section{KESIMPULAN DAN SARAN}

Kesimpulan

Berdasarkan hasil dan pembahasan, dapat ditarik kesimpulan sebagi berikut: (1) Rata-rata biaya produksi usaha budidaya lebah madu Trigona $s p$ di Kecamatan Bayan Kabupaten Lombok Utara sebesar Rp 5.270/stup atau Rp 247.668/proses produksi atau Rp 495.336/tahun. Produksi madu yang dihasilkan petani lebah madu Trigona sp sebanyak 0,16 liter/stup atau 7,625 liter/proses produksi atau 15,25 liter/tahun dengan harga Rp. 225.000/liter, maka diperoleh nilai penerimaan sebesar Rp36.503/stup atau Rp 1.715.625/proses produksi atau Rp. 3.431.250/tahun. Sementara itu rata-rata pendapatan yang diperoleh petani lebah madu sebesar Rp 31.233/stup Rp 1.467.957/proses produksi atau Rp 2.935.914/tahun; (2) Kontribusi usaha budidaya lebah madu Trigona sp terhadap pendapatan rumah tangga petani di Kecamatan Bayan Kabupaten Lombok Utara sebesar Rp 2.935.914 (21,68\%) dari total pendapatan Rp 13.695.676/tahun yang bersumber dari sektor pertanian Rp 6.254.762 (46,19\%) dan usaha non pertanian Rp. 4.350 .000 (32,13\%); (3) Kendala utama yang dihadapi petani dalam melakukan usaha budidaya lebah madu Trigona $s p$ di Kecamatan Bayan Kabupaten Lombok Utara adalah koloni dan teknologi yang dialami oleh seluruh petani responden dengan persentase $100 \%$, modal sebanyak $87,50 \%$, iklim $62,50 \%$ pendidikan/keterampilan $35 \%$, hama $17,50 \%$ dan pakan $10 \%$.

Saran

Berdasarkan kesimpulan maka dapat diajukan saran sebagai berikut: (1) Diharapkan kepada petani, agar dapat meningkatkan usaha budidaya lebah madu Trigona $s p$, yang mana usaha ini dapat memberikan pendapatan yang cukup besar sebagai usaha sampingan; (2) Diharapkan kepada petani untuk lebih memperhtikan bagaimana kemasan dari produksi madu, agar terlihat lebih menarik dan memiliki nilai jual yang lebih tinggi; (3) Diharapkan kepada pemerintah agar lebih memperhatikan petani dalam memberikan bantuan terutama bantuan berupa stup, koloni dan teknologi; (3) Diharapkan kepada pemerintah atau lembaga terkait untuk memberikan pelatihan-pelatihan kepada petani, agar mampu mengolah hasil dari lebah madu Trigona $s p$ selain hasil madu itu sendiri.

\section{DAFTAR PUSTAKA}

Filly, N.N., 2018. Kontribusi Usaha Budidaya Lebah Madu Terhadap Pendapatan dan Kesejahteraan Petani Lebah Madu Desa Buana Sakti Kecamatan Batanghari Kabupaten Lampung Timur. [Skripsi]. Jurusan Agribisnis, Fakultas Pertanian Universitas Lampung. Bandar Lampung. Indonesia. http //digilib. unila.ac.id/30546/2/Skripsi\%20Tanpa\%20Bab\%20Pembahasan.pdf. (11 November 2018).

Ichwan F., Yoza D, Budiani E.S. 2016. Prospek Pengembangan Budidaya Lebah Trigona sp di Sekitar Hutan Larangan Adat Rumbio Kabupaten Kampar. Jom Faperta UR Vol 3 No 2. https: // media 
.neliti.com/media/publications/184969-ID-prospek pengembangan-budidaya-lebah-trig.pdf.

November 2018).

Nazir, Mohammad. 2011. Metode Penelitian. Ghalia Indonesia. Bogor.

Suratiyah, Ken. 2009. Ilmu Usahatani. Cetakan ke-3. Penebar Swadaya. Jakarta.

Supriyanto, S. 2017. Analisis Kontribusi Usaha Lebah Madu Terhadap Pendapatan Keluarga Tani (Studi Kasus) di Desa Sipatuhu Kecamatan Banding Agung Kabupaten Oku Selatan. Agritech: Vol. XIX No. 2 Desember 2017 : 137-143. http://jurnalnasional.ump.ac.id/index.php/ AGRITECH /article/view /251 0/ 1906. (03 Desember 2018).

Wardoyo M.R., Lamusa A., Afandi. 2016. Analisis Kelayakan Usaha Ternak Lebah Madu Jaya Makmur di Desa Jono Oge Kecamatan Sigi Biromaru Kabupaten Sigi. Agrotekbis 4 (1): 8490.http://jurnal.untad.ac.id/jurnal/index.php/Agrotekbis/article/view/ 5590. (18 November 2018).

Zulfikri, Dolorosa Eva dan Komariyati. 2014. Analisis Kontribusi Usaha Ternak Sapi Potong Terhadap Pendapatan Rumah Tangga Petani di Kecamatan Tebas Kabupaten Sambas. Vokasi, Th. X, No 1. http://repository. polnep. ac.id/xmlui/handle/123 456789/1224. (14 Januari 2019). 